\title{
Effects of Dust Accumulation and Removal on Radiator Surfaces on Mars
}

James R. Gaier, Marla E. Perez-Davis, and Sharon K. Rutledge Lewis Research Center Cleveland, Ohio

Deborah Hotes and Raymond Olle Cleveland State University Cleveland, Ohio

\section{DISCLAIMER} Government. Neither the United States Government nor any agency thereof, nor any of their employees, makes any warranty, express or implied, or assumes any legal liability or responsibility for the accuracy, completeness, or usefulness of any information, apparatus, product, or process disclosed, or represents that its use would not infringe privately owned rights. Reference herein to any specific commercial product, process, or service by trade name, trademark, manufacturer, or otherwise does not necessarily constitute or imply its endorsement, recommendation, or favoring by the United States Government or any agency thereof. The views and opinions of authors expressed herein do not necessarily state or reflect those of the United States Government or any agency thereof.

\section{NMSN}




\section{DISCLAIMER}

This report was prepared as an account of work sponsored by an agency of the United States Government. Neither the United States Government nor any agency Thereof, nor any of their employees, makes any warranty, express or implied, or assumes any legal liability or responsibility for the accuracy, completeness, or usefulness of any information, apparatus, product, or process disclosed, or represents that its use would not infringe privately owned rights. Reference herein to any specific commercial product, process, or service by trade name, trademark, manufacturer, or otherwise does not necessarily constitute or imply its endorsement, recommendation, or favoring by the United States Government or any agency thereof. The views and opinions of authors expressed herein do not necessarily state or reflect those of the United States Government or any agency thereof. 


\section{DISCLAIMER}

Portions of this document may be illegible in electronic image products. Images are produced from the best available original document. 


\author{
James R. Gaier, Marla E. Perez-Davis, and Sharon K. Rutledge \\ NASA Lewis Research Center \\ Cleveland, $\mathrm{OH} 44135$ \\ Deborah Hotes and Raymond Olle \\ Cleveland State University \\ Cleveland, $\mathrm{OH} 44115$
}

\begin{abstract}
SUMMARY
Tests were carried out to assess the impact of wind blown dust accumulation and abrasion on radiator surfaces on Mars. High emittance arc-textured copper $(\mathrm{Cu})$ and niobium-1\%-zirconium (Nb-1\% Zr) samples were subjected to basaltic dust laden wind at Martian pressure (1000 Pa) at speeds varying from 19 to $97 \mathrm{~m} / \mathrm{s}$ in the Martian Surface Wind Tunnel at NASA Ames Research Center. The effect of accumulated dust was also observed by pre-dusting some of the samples before the test. Radiator degradation was determined by measuring the change in the emittance after dust was deposited and/or removed. The principal mode of degradation was abrasion. Arc-textured $\mathrm{Nb}-1 \% \mathrm{Zr}$ proved to be more susceptible to degradation than $\mathrm{Cu}$, and pre-dusting appeared to have lessened the abrasion.
\end{abstract}

\title{
INTRODUCTION
}

By presidential directive, NASA has initiated a technology development program to enable a manned mission to Mars. Lewis Research Center has been given the lead role in providing the technology for Martian surface power systems. Careful consideration must be given to the environment in which these power systems will work, for there are several hazardous constituents within the environment. Potential threats include low ambient temperatures $(150-300 \mathrm{~K})$, wide daily temperature swings ( $20-50 \mathrm{~K}$ per day), highly reactive species in the soil (probably peroxides and superoxides), and large quantities of dust. The focus of this report will be on dust which is elevated by dust storms, often global in extent, and which will settle out onto power system components.

Tens of kilowatts of power will be required even for a temporarily manned outpost on the Martian surface, and preliminary studies (ref 1.) indicate that nuclear power systems are attractive for meeting those requirements. A necessary component of any nuclear power system is radiators to maintain the cold-end temperature.

There are several candidate materials for power system radiators. The radiators must have high thermal conductivity, so that heat can be distributed evenly throughout the radiator, and high emittance, so that the heat can be radiated away efficiently. The emittance of any material can be increased dramatically by increasing its surface area. A 
promising technology to accomplish this is through microscopically textured surfaces. A technique called arc-texturing can be used to form a textured surface through spot melting and resolidification of the surface with some incorporation of carbon from the arc into the metal to enhance its emittance by as much as a factor of 14 (ref. 2).

Dust, elevated by either local or global storms, could have several adverse effects on radiator performance. The temperature sensors on the Viking landers showed that during a dust storm the mean atmospheric temperature decreases by about $10 \mathrm{~K}$, and the daily variation decreases by about $20 \mathrm{~K}$ when the atmosphere is filled with dust (ref. 3). Although this will aid the power system by providing a slightly lower cold end temperature, at times during the night this will raise the ultimate cold end temperature, though perhaps not by much if the radiators run at high enough temperatures to make this effect small. More seriously, the opacity of the atmosphere increases to an optical depth as high as 5 (ref. 3 ). This will make radiative heat transfer more difficult. Also, after the storms dust will settle out on the radiator surfaces. We have shown in an earlier study (ref. 4) that the magnitude of this effect is strongly dependent upon the dust composition which, unfortunately, is not well known. With some model dusts the emittance was lowered by as much as a factor of two. Lastly, aeolian removal of the dust from the radiator surfaces, or wind driven dust could abrade those surfaces, with possible degradation of radiator performance. The purpose of this study is to examine the effects of settled blowing dust on the performance of these radiator materials.

\section{METHODS AND MATERIALS}

Coupons of two candidate radiator materials, copper $(\mathrm{Cu})$ and niobium with 1 percent zirconium $(\mathrm{Nb}-1 \% \mathrm{Zr}$ ) were fabricated to be $2.4 \mathrm{~cm}$ in diameter. Their untextured thermal emittance was calculated from hemispherical reflection measurements using a Perkin-Elmer Lambda-9 spectrophotometer and a Hohlraum reflectometer. The spectrophotometer was used to measure the spectral reflectance over wavelengths from 0.4 to $2.5 \mu \mathrm{m}$, and the Hohlraum to obtain spectral emittance over wavelengths from 1.5 to 15 $\mu \mathrm{m}$.

Since the sample is at room temperature during both measurements, adjustments must be made to obtain the emittance (equal to 1 - reflectance) as a function of temperature. Using the method described by Mirtich and Mark (ref. 5) the spectral emittance is convoluted with a blackbody spectrum for each temperature to obtain the total integrated emittance. The data from both instruments were combined to form a smooth transition from the ultra-violet through infra-red and to allow calculation of the integrated thermal emittance over the temperature range of 300 to $3000 \mathrm{~K}$.

Four coupons of each metal were arc-textured with a carbon arc operated within a nitrogen-argon atmosphere by the method of Banks et al. (ref. 2). There are two consequences of arc-texturing which increase the emittance of the sample. First, the arc melts a small area of the surface which then resolidifies. This results in a microscopic roughening of the surface, increasing its surface area. Second, carbon is sputtered from the electrode and deposited on the surface. Carbon has an emittance which is much higher than that of the metal. 
After the coupons were arc-textured the emittance of the textured coupons was remeasured using the above procedure. Then, after the MARSWIT tests, the emittance of the coupons was measured a third time. Scanning electron microscopy (SEM) and energy dispersive $\mathrm{x}$-ray spectroscopy (EDS) were used to characterize the sample surfaces after the MARSWIT tests.

The textured coupons were placed in specially designed sample holders, each held in place by a thin metal retaining ring which was secured by means of foil tabs stretched across three cords of the circle. A spring held them flush with the surface. The radiator sample holders were oriented at a tilt angle of $45^{\circ}$, which was the angle found to maximize the wind effects (ref. 7). The sample holders could also orient the sample horizontally to facilitate the application of a layer of dust in the dusting chamber.

The dust used to coat the samples was a basalt known as "trap rock". This material is believed to be chemically similar to the dusts that are found on Mars. The fact that this dust has a grey-green color, however, suggests that there are significant differences. The particle size of this material ranged from about $5-38 \mu \mathrm{m}$. Particles this size could be elevated by the strong Martian winds present during storms, but would settle out during more common conditions. It should be noted that the purpose of these experiments was not to try to simulate Martian soil, but to determine the general effects of blowing dust on radiator surfaces.

In some of the cases the sample holders were placed in a dusting chamber in which the dust was elevated using dry air and allowed to settle on the samples. Details about the method of dusting and characterization of the dust are described in detail elsewhere (ref. 8). The uniformity and extent of the dust deposition was monitored optically. Optical transmittance measurements were made by sliding the transmittance measuring device over transparent coverslips which were also mounted in the sample holder. Further details about the measurement, as well as dust clearing from the smooth transparent surfaces are reported elsewhere (ref. 9).

The winds on Mars were simulated using the Martian Surface Wind Tunnel (MARSWIT) at NASA Ames Research Center. The MARSWIT is a low pressure (down to a few hundred $\mathrm{Pa}$ ) wind tunnel $14 \mathrm{~m}$ in length with a $1 \mathrm{~m}$ by $1.1 \mathrm{~m}$ by $1.1 \mathrm{~m}$ test section located $5 \mathrm{~m}$ from the tunnel's entrance. This flow-through wind tunnel is located within a $4,000 \mathrm{~m}^{3}$ vacuum chamber. Its characteristics are described in detail elsewhere (ref. 10). The samples were placed in the MARSWIT and tested under the conditions listed in table I.

The basaltic dust was fed through a hopper into the top of the MARSWIT, near the entrance. First the wind was generated in the MARSWIT at a velocity below that which would clear dust off of the pre-dusted samples. Then the hopper was started, feeding the dust into the air stream. Immediately thereafter the wind velocity was increased to the test conditions. The time reported in table I is the time spent at the maximum speed. The finer particles were carried along the wind stream and struck the samples, much as would happen during a dust storm on Mars. The MARSWIT was shut down before the hopper was turned off, so there was no time when high velocity clear air hit the samples. Both initially clean and initially dusted samples were included in these tests. 


\section{RESULTS AND DISCUSSION}

The degradation of the radiator surfaces is characterized by the change in the spectral emittance before and after exposure to the dust. The average initial emittance of the arc-textured $\mathrm{Cu}$ and $\mathrm{Nb}-1 \% \mathrm{Zr}$ samples are shown in figure 1. The values for copper are only calculated to $1350 \mathrm{~K}$ because copper melts above that temperature. It is not clear what the operating temperature for radiators on the Martian surface will be, but relatively low power radiators, such as those cooling regenerative fuel cells would probably float under 400 $\mathrm{K}$, while those associated with cooling for heat engines would probably work in the 800 $1200 \mathrm{~K}$ range (ref. 1). Although in these temperature ranges these arc-textured $\mathrm{Cu}$ samples had emittances which were 8 to 10 percent higher than those of the $\mathrm{Nb}-1 \% \mathrm{Zr}$ samples, it should be pointed out that in general $\mathrm{Nb}-1 \% \mathrm{Zr}$ can be fabricated with an emittance as high as arc-textured copper.

Three tests were run with the radiator surfaces initially clear of dust. Both $\mathrm{Cu}$ and $\mathrm{Nb}-1 \% \mathrm{Zr}$ were subjected to $22 \mathrm{~m} / \mathrm{s}$ and $58 \mathrm{~m} / \mathrm{s}$ winds. These represent velocities below and above respectively the threshold velocities for clearing dust off of $45^{\circ}$ tilted surfaces with clear air at Martian conditions (ref. 7). In addition, a sample of $\mathrm{Nb}-1 \% \mathrm{Zr}$ was subjected to dust laden winds at the maximum velocity of the MARSWIT. The results of these tests are shown in figure 2 .

It was observed in all cases that dust accumulated on the samples. This observation was verified by concurrent tests with optical specular transmittance measurements on coverslips used to simulate photovoltaic cover-glasses (ref. 9). The accumulation occurred despite the fact that in clear wind the threshold clearing velocity is about $30 \mathrm{~m} / \mathrm{s}$ (ref. 7).

If the emittances of the $\mathrm{Nb}-1 \% \mathrm{Zr}$ samples at 22,58 , and $97 \mathrm{~m} / \mathrm{s}$ are compared, then a large drop in emittance can be seen as the wind velocity increases. One would suspect that erosion of the arc-textured surface by the wind-blown dust might be the cause. Inspection of the surfaces shows that this is indeed the case. In the case of the $\mathrm{Nb}-1 \% \mathrm{Zr}$ subjected to $97 \mathrm{~m} / \mathrm{s}$ dust-laden wind, there is an obvious change in the color of the sample. It was not clear from simple inspection, however, whether the color change was due to abrasion of the carbon from the surface, or if the dust was simply embedded in the sample.

Figure 3 shows a boundary area between protected and unprotected regions on the $\mathrm{Nb}-1 \% \mathrm{Zr}$ sample subjected to $97 \mathrm{~m} / \mathrm{s}$ dust-laden wind. Etch pits from the arc-texturing process are visible in both regions, but carbon deposits which cover over half of the protected region are nearly absent from the unprotected region. EDS analysis also showed an absence of carbon in the unprotected region. If the dust were packed in a thin layer on top of carbon regions this would be detectable in the EDS which would have a penetration depth of tens of $\mu \mathrm{m}$. A build-up of dust that thick would have been clearly visible in other high resolution micrographs which were taken. Thus, in the case of $\mathrm{Nb}-1 \% \mathrm{Zr}$ the surface was clearly abraded.

The differences between the two $\mathrm{Cu}$ samples subjected to 22 and $58 \mathrm{~m} / \mathrm{s}$ winds are very slight. The emittance of the $58 \mathrm{~m} / \mathrm{s}$ sample actually appears to be slightly higher. If the original emittances are considered, however, it is found that the two data sets are identical to within 3 percent. Given that the reproducibility of the instrument is of the same order, no effect of the increased wind speed can be determined for this case. 
It is also noted that the Cu samples appear to be less susceptible to degradation than do those of $\mathrm{Nb}-1 \% \mathrm{Zr}$. It is obvious that abrasion is the principal mode of degradation in the $\mathrm{Cu}$ samples as well as the $\mathrm{Nb}-1 \% \mathrm{Zr}$. After subjection to the $97 \mathrm{~m} / \mathrm{s}$ dust-laden wind there is a distinct copper color to the sample, which was initially black. Given that the basalt is a grey-green color abrasion is clearly the mechanism. This is somewhat puzzling since $\mathrm{Cu}$ is a softer metal. Of course the surface has been modified by the texturing process, and so its abrasive properties would not be that of the bulk.

Figure 4 illustrates the results for samples which were initially dusted, and then subjected to the dust laden wind. Comparison of the Cu samples subjected to 19 and 97 $\mathrm{m} / \mathrm{s}$ winds reveals that the emittance degrades more in high velocity winds. As in the case of initially clear samples, this supports an abrasion model.

If these data are compared to those resulting from similar conditions for the initially clear samples an interesting trend emerges. Samples which have an initial covering of dust tend to degrade less than those which are initially clear. This is true when the pre-dusted $\mathrm{Cu}$ is compared with the clear $\mathrm{Nb}-1 \% \mathrm{Zr}$ that was run simultaneously at $97 \mathrm{~m} / \mathrm{s}$, and when the dusted $19 \mathrm{~m} / \mathrm{s}$ data are compared to the clear $22 \mathrm{~m} / \mathrm{s}$ data. This could be the result of the coat of dust protecting the surface from abrasion. It is easy to envision a protective mechanism whereby when an airborne particle strikes a clean surface much of its kinetic energy goes directly to deforming and fracturing that surface. If, however, it strikes another particle then much of its kinetic energy is transferred to the already deposited particle to put it into motion. Although this is an interesting trend, it is not proven in this experiment since the $\mathrm{Nb}-1 \% \mathrm{Zr}$ does undergo more degradation than $\mathrm{Cu}$, which could account for the $97 \mathrm{~m} / \mathrm{s}$ data, and dynamic pressure at $22 \mathrm{~m} / \mathrm{s}$ is 34 percent higher than at $19 \mathrm{~m} / \mathrm{s}$, which could account for those differences.

It should be noted that a significant fraction of the pre-settled dust was cleared by the dust laden wind. This was also verified by the specular transmittance measurements (ref. 9). Given time and dust laden wind, an equilibrium coverage of dust accumulates which would make the predusted indistinguishable from those which were initially clear.

\section{CONCLUSIONS}

Arc-textured copper $(\mathrm{Cu})$ and niobium-1\%-zirconium $(\mathrm{Nb}-1 \% \mathrm{Zr})$ samples were subjected to basaltic dust laden wind at Martian pressure (1000 $\mathrm{Pa}$ ) at speeds varying from 19 to $97 \mathrm{~m} / \mathrm{s}$ in the MARSWIT. The effect of accumulated dust was also observed by predusting some of the samples before the test. Exposure to dust-laden wind resulted in samples with dust deposition intermediate between the initially clear and the initially dusted samples, and seemed to converge to a similar equilibrium value. Radiator degradation, as determined by measuring the change in the 300 to $3000 \mathrm{~K}$ emittance after dust was deposited and/or removed, was found to increase with increasing wind speed. The principal mode of degradation appeared to be abrasion of the carbon from the arc-textured surfaces. Samples which had dust covering them before the test may have abraded less than their initially dust-free counterparts. Arc-textured $\mathrm{Nb}-1 \% \mathrm{Zr}$ proved to be more susceptible to abrasive degradation than arc-textured $\mathrm{Cu}$. 


\section{ACKNOWLEDGMENTS}

The authors gratefully acknowledge the support of R. Leach of Arizona State University for his assistance with the MARSWIT, as well as the support staff at NASA Ames Research Center, and M. Marabito of Cleveland State University for his valuable assistance with the sample holders.

\section{REFERENCES}

1. Sovie, R.J.; and Bozek, J.M.: Nuclear Power Systems for Lunar and Mars Exploration, NASA TM-103168, 1990.

2. Banks, B.A., et al.: Arc-Textured Metal Surfaces for High Thermal Emittance Space Radiators, NASA TM-100894, 1988.

3. Tillman, J.E., Martian Meteorology and Dust Storms from Viking Observations, The Case for Mars II, C.P. McKay, ed., Univelt, Inc., San Diego, CA, 1985, pp. 333-342 (Science and Technology Series, Vol. 62, 1985).

4. Hunt, G.E., Thermal Infrared Properties of the Martian Atmosphere. IV -Predictions of the Presence of Dust and Ice Clouds from Viking IRTM Spectral Measurements -- IR Thermal Mapper, J. Geophys. Res., vol. 84, June 10, 1979 pp. 2865-2874.

5. Gaier, J.R., et al., Aeolian Removal of Dust From Radiator Surfaces on Mars, NASA TM-103205, 1990.

6. Mirtich, M.J.; and Mark, H.: Feasibility of Accelerating Micron-Size Particles in Shock-Tube Flows for Hypervelocity Degradation of Reflective Surfaces, NASA TND-3187, 1966.

7. Gaier, J.R.; Perez-Davis, M.E.; and Marabito, M.: Aeolian Removal of Dust from Photovoltaic Surfaces on Mars, NASA TM-102507, 1990.

8. Perez-Davis, M.E., et al., Simulation of Martian Dust Accumulation on Surfaces, Presented at the 16th Space Simulation Conference, NASA CP-3096, 1990, pp. 447451.

9. Gaier, J.R.; and Perez-Davis, M.E.: Effects of Windblown Dust on Photovoltaic Surfaces on Mars, In preparation, 1991.

10. Greeley, R., et al., Dust Storms on Mars: Considerations and Simulations, NASA TM-78423, 1977. 
Table I -- MARSWIT Condilions Examined

\begin{tabular}{llllll}
\hline Wind Velocity & Stalic Prcs. & Dynamic Prcs. & Tcmp. & Time & Pre-Dusicd \\
\hline $19 \mathrm{~m} / \mathrm{s}$ & $1000 \mathrm{~Pa}$ & $6.96 \mathrm{~Pa}$ & $284 \mathrm{~K}$ & $45 \mathrm{sec}$ & Ycs \\
22 & 1000 & 9.33 & 283 & 45 & No \\
55 & 1000 & 58.3 & 284 & 15 & Ycs \\
58 & 1000 & 64.9 & 283 & 45 & No \\
97 & 1000 & 181 & 286 & 5 & $*$ \\
\end{tabular}

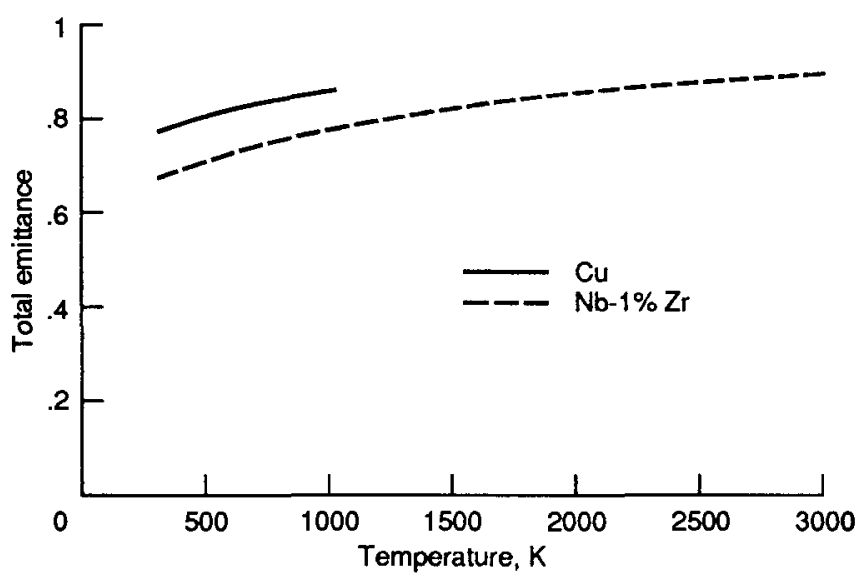

Figure 1.-Initial total emittance of radiator samples.

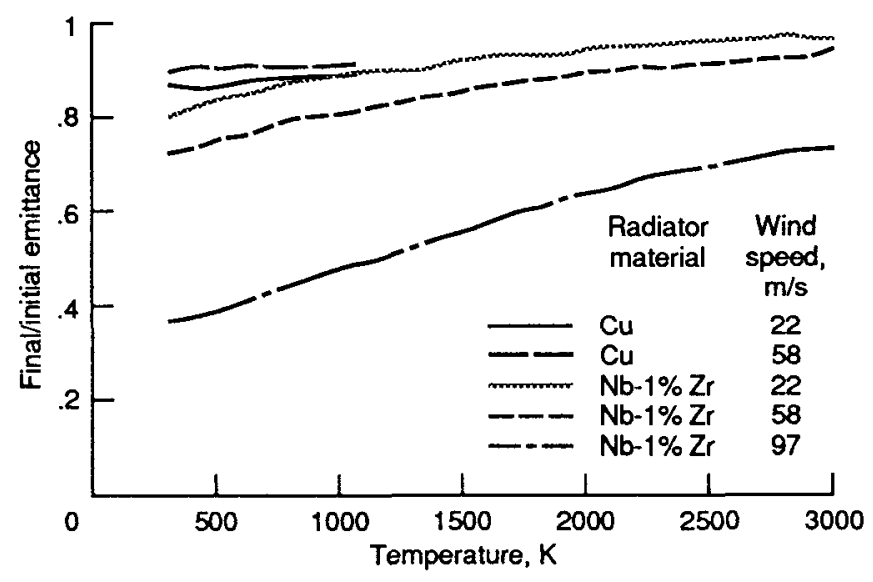

Figure 2.-Degradation of initially clear radiator samples subjected to dust laden wind. 


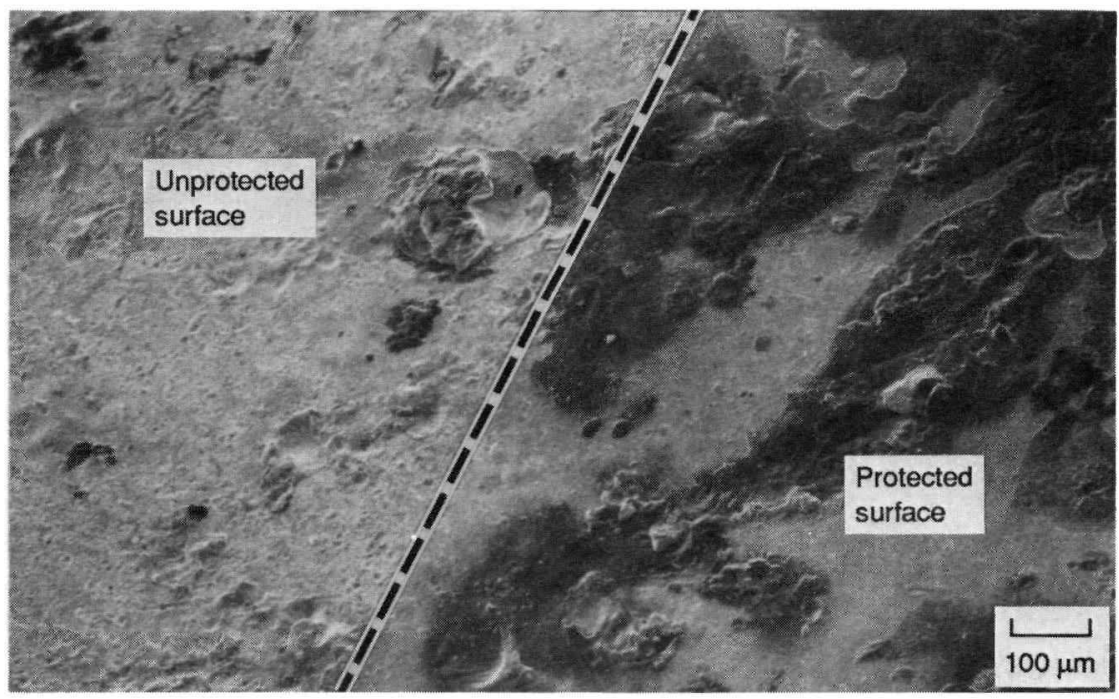

Figure 3.-Abrasion of arc-textured $\mathrm{Nb}-1 \% \mathrm{Zr}$ surface on exposure to $97 \mathrm{~m} / \mathrm{s}$ dust-laden wind.

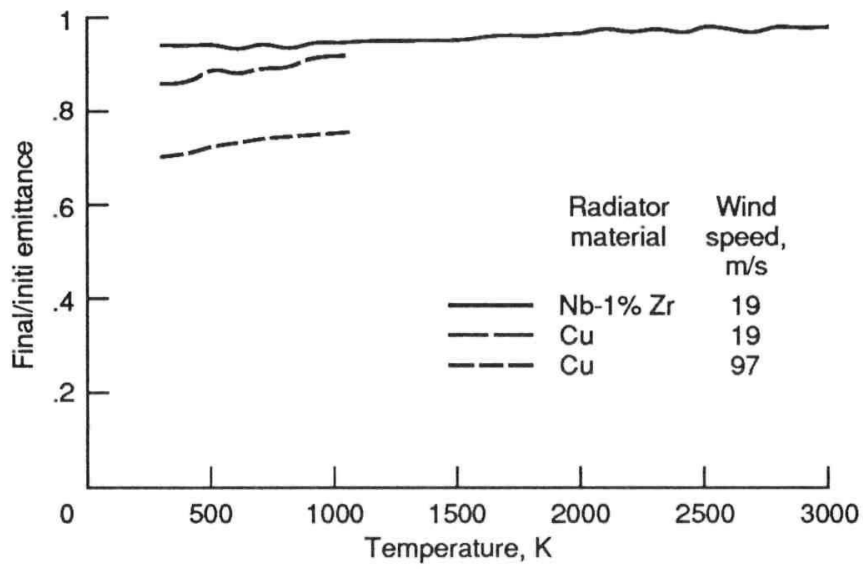

Figure 4.-Degradation of initially dusted radiator samples subjected to dust laden wind. 


\begin{tabular}{|c|c|c|c|c|}
\hline \multicolumn{5}{|c|}{ Report Documentation Page } \\
\hline $\begin{array}{l}\text { 1. Report No. } \\
\text { NASA TM-103704 }\end{array}$ & \multicolumn{2}{|c|}{ 2. Government Accession No } & \multicolumn{2}{|c|}{ 3. Recipient's Catalog No } \\
\hline \multirow{2}{*}{\multicolumn{3}{|c|}{$\begin{array}{l}\text { 4. Title and Subtitle } \\
\text { Effects of Dust Accumulation and Removal on Radiator Surface on Mars }\end{array}$}} & \multicolumn{2}{|c|}{$\begin{array}{l}\text { 5. Report Date } \\
\text { January } 1991\end{array}$} \\
\hline & & & \multicolumn{2}{|c|}{ 6. Performing Organization Code } \\
\hline \multirow{2}{*}{\multicolumn{3}{|c|}{$\begin{array}{l}\text { James R. Gaier, Marla E. Perez-Davis, Sharon K. Rutledge, Deborah Hotes, } \\
\text { and Raymond Olle }\end{array}$}} & \multicolumn{2}{|c|}{$\begin{array}{l}\text { 8. Performing Organization Report No. } \\
\text { E-5841 }\end{array}$} \\
\hline & & & \multicolumn{2}{|l|}{$\begin{array}{l}10 \text { Work Unit No. } \\
591-14-41\end{array}$} \\
\hline \multirow{2}{*}{\multicolumn{3}{|c|}{$\begin{array}{l}\text { 9. Performing Organization Name and Address } \\
\text { National Aeronautics and Space Administration } \\
\text { Lewis Research Center } \\
\text { Cleveland, Ohio 44135-3191 }\end{array}$}} & \multicolumn{2}{|c|}{11 Contract or Grant No. } \\
\hline & & & \multirow{2}{*}{\multicolumn{2}{|c|}{$\begin{array}{l}\text { 13. Type of Report and Period Covered } \\
\text { Technical Memorandum }\end{array}$}} \\
\hline \multirow{2}{*}{\multicolumn{3}{|c|}{$\begin{array}{l}\text { 12. Sponsoring Agency Name and Address } \\
\text { National Aeronautics and Space Administration } \\
\text { Washington, D.C. 20546-0001 }\end{array}$}} & & \\
\hline & & & \multicolumn{2}{|c|}{14 Sponsoring Agency Code } \\
\hline \multicolumn{5}{|c|}{$\begin{array}{l}\text { Portions of this material were presented at the 8th Symposium on Space Nuclear Power Systems cosponsored by } \\
\text { the University of New Mexico, National Aeronautics and Space Administration, Strategic Defense Initiative } \\
\text { Organization, U.S. Department of Energy, and U.S. Air Force, Albuquerque, New Mexico, January 6-10, } 1991 . \\
\text { James R. Gaier, Marla E. Perez-Davis, and Sharon K. Rutledge, NASA Lewis Research Center. Deborah Hotes } \\
\text { and Raymond Olle, Cleveland State University, Cleveland, Ohio } 44115 \text { (work funded by NASA Cooperative } \\
\text { Agreement NCC3-19). }\end{array}$} \\
\hline \multicolumn{5}{|l|}{$\begin{array}{l}16 \text { Abstract } \\
\text { Tests were carried out to as } \\
\text { Mars. High emittance arc-te } \\
\text { basaltic dust laden wind at } \\
\text { Surface Wind Tunnel at NA } \\
\text { dusting some of the samples } \\
\text { emittance after dust was de } \\
\text { textured Nb-1\%Zr proved to } \\
\text { lessened the abrasion. }\end{array}$} \\
\hline \multicolumn{2}{|c|}{$\begin{array}{l}\text { 17. Key Words (Suggested by Author(s)) } \\
\text { Mars; Dust accumulation; Radiator; Abrasion; } \\
\text { Power systems }\end{array}$} & \multicolumn{3}{|c|}{$\begin{array}{l}18 \text { Distribution Statement } \\
\text { Unclassified - Unlimited } \\
\text { Subject Category } 20\end{array}$} \\
\hline $\begin{array}{l}\text { 19. Security Classif. (of this report) } \\
\text { Unclassified }\end{array}$ & 20. Secu & $\begin{array}{l}\text { f this page) } \\
\text { assified }\end{array}$ & $\begin{array}{c}\text { 21. No of pages } \\
10\end{array}$ & $\begin{array}{r}\text { 22. } \text { Price* }^{*} \\
\mathrm{~A} 02\end{array}$ \\
\hline
\end{tabular}


National Aeronautics and

Space Administration,

Lewis Research Center

Cleveland, Ohio 44135

Otficial Business

Penalty for Private Use $\mathbf{\$ 3 0 0}$
FOUATH CLASS MAIL

ADDRESS CORRECTION REQUESTED
||||||

National Aeronautics and

Space Administration

NASA 451 